\title{
Effect of Adding White Tea Leaves Powder (Camellia sinensis) to Broiler Chicken Diets
} on Some Biochemical Blood Parameters

\author{
Hamid, A. F. ${ }^{1}$; EL-Gendi, G. M $^{2}$;Nihad A. A ${ }^{3}$. and El-Garhy, O. H. ${ }^{4 *}$ \\ 1,2,4 Animal Production Dept., Fac. of Agric., Benha Univ., Egypt. \\ ${ }^{3}$ College of Agriculture, Al-Qasim green University. Iraq. \\ * Corresponding author: osama.alsayed@ fagr.bu.edu.eg
}

\begin{abstract}
This study aimed to evaluate the effect of dietary supplementation of white tea leaves powder (Camellia sinensis) on some biochemical parameters of broiler chickens. A total number of 360 one-day old unsexed broiler chicks (Ross 308) with similar average initial body weight were used. Chicks were randomly divided into two main experimental groups (each of 180 chicks). The $1^{\text {st }}$ main experimental group was provided with normal water (NW) while the $2^{\text {nd }}$ main experimental group was exposing to the oxidative stress by providing normal water with $0.5 \%$ of $\mathrm{H}_{2} \mathrm{O}_{2}$, each main experimental group was divided into four treatments (each of 45 chicks), with three replicates (15 chicks /replicate), according to feeding diets supplemented with white tea powder were (T1): chicks fed basal diet without adding white tea powder, while the second (T2), third (T3) and fourth (T4) group were chicks fed basal diet supplemented with 1, 2 and $3 \mathrm{~g}$ white tea leaves powder/kg diet, respectively. The results obtained showed that broiler chicks provided by the normal water has the better biochemical blood parameters than those received the oxidative water. Broiler chicks fed diets supplemented with different levels of white tea leaves powder improve some physiological and biochemical blood parameters than control group. From the results obtained in this study, it could be recommended with feeding broiler chicks (Ross 308) on diet supplemented with $3 \mathrm{~g} / \mathrm{kg}$ feed and provided with normal water seemed to be adequate to achieve the favorable results for improve the biochemical and physiological parameters.
\end{abstract}

Keywords: White tea leaves, Biochemical blood parameters, Broiler chickens.

\section{Introduction}

In the last decades, the widely use of manufactured chemical antibiotics to prevention and control of poultry diseases and to use it as growth promoters. However, the utility of antimicrobial agents as a preventive measure has been questioning, given extensive documentation of the evolution of antimicrobial resistance among pathogenic bacteria further to the residues of antibiotics in produced birds bodies which has serious effect on consumers. This may lead to appear the unknown modern human diseases before and began chronic diseases. Therefore, the World Health Organization (WHO) has recently identified antibiotic resistance as a major problem for public health on a global scale. For this reason, an overflow of studies is triggered to introduce suitable alternatives for antibiotics. Medicinal plants and their products including plant extracts or essential oils are introduced as candidates for use in broiler diets in which their beneficial effects as phytogenic feed additives have been proven and their physiological influence and therapeutic activity of humans and animals as well (Bölïkbaşi and Erhan, 2007; Soltan et al., 2008 and Dalkilic et al., 2009).

White tea is one of the common teas in the developed countries which known as the first interested and traditional drink. Japan and China are the most prolific producing countries for white tea. It is one of the tea varieties that produced by picking the small buds and small leaves of tea before turned into a green color. Then, it is carefully cared for after the cut, drying it very carefully, his is what makes it the rarest of tea types and has the ability to revitalize the body and increased of concentration and the heatdecreasing of the body and resistant to thirst and is used for treating because it contains many chemical compounds effective such as compounds Flavonoids, Catechin with higher proportion concentration, therefore, it is also act as an effective antioxidant (Antan and Shella, 2003 and Saffari and Sadrzadeh, 2004). White tea contains Fluoride, and many antioxidants such as Polyphenole, methyl Xanthine, Theobromine, Caffeine, tannic acid, and many important compounds (Gargi et al., 2017). Manganese also is one of the most common minerals in white tea, which plays an important role to improve of the digestion of proteins and is very important for bone tissues and connective tissues (Costa et al., 2002 and Wang and Ho, 2009). In addition, it's contains of vitamins, especially vitamin E and C (Unachukwu et al., 2010).

Since, there are a few researches carried out on the effect of using white tea on poultry, this study was aimed to evaluate and find out the influence of adding white tea leaves powder (Camellia sinensis) to the broilers (Ross 308) diets in some biochemical blood parameters.

\section{Materials and Methods}

This experiment was carried out in the poultry research farm belonging to the College of Agriculture, Al-Qasim Green University, in order to evaluate the 
effect of type of water and adding different levels of white tea leaves powder (Camellia sinensis) to the diet on the physiological performance of broiler chickens. A total number of 360 one-day old unsexed broiler chicks (Ross 308) with similar average initial body weight, obtained from Al-Anwar hatchers in Babylon province, Iraq were used. Chicks were raised in floor room with dimensions of $(3 \times 10 \times 45 \mathrm{~m})$, divided into pens with the dimensions of $1.5 \times 1 \mathrm{~m} / \mathrm{pen}$. Chicks were randomly divided into two main experimental groups (each of 180 chicks). The $1^{\text {st }}$ main experimental group was provided with normal water $(\mathrm{NW})$ while, the $2^{\text {nd }}$ main experimental group was exposing to the oxidative stress by providing normal water with $0.5 \%$ of $\mathrm{H}_{2} \mathrm{O}_{2}$, each main group was divided into four treatments (each of 45 chicks), with three replicates (15 chicks /replicate), according to the feeding diets supplemented with White tea leaves powder were (T1): chicks fed basal diet without adding white tea powder and considered as control group, while chicks of T2, T3 and T4 groups fed basal diet supplemented with white tea leaves powder at levels of 1, 2 and $3 \mathrm{~g}$ $/ \mathrm{kg}$ diet, respectively. Wood shaving was used at 8 $\mathrm{cm}$. The continuous lighting program was used for 23 hours, with an hour of darkness daily. The feed and water provided Ad-libitum. All birds were reared under the same managerial and hygienic conditions. Chicks were fed starter diet during the first three weeks of age then replaced by grower diet from the $22^{\text {nd }}$ day up to the end of experiment ( 35 day). The basal diets were formulated according to the recommended requirements of NRC (1994), as showed in Table (1).

Table 1. The proportions of feed materials used in the formation of the initiator and final diets and the calculated chemical composition of the diets

\begin{tabular}{lcc}
\hline Ingredients $(\%)$ & $\begin{array}{c}\text { Starter } \\
(\mathbf{0}-\mathbf{3}) \mathbf{w k s}\end{array}$ & $\begin{array}{c}\text { Grower } \\
\mathbf{( 4 - 5 )} \mathbf{~ w k s} .\end{array}$ \\
\hline Yellow corn & 30.00 & 40.00 \\
Wheat & 28.25 & 24.00 \\
Soybean meal (48\% protein) & 31.75 & 24.80 \\
Protein concentrate & 5.00 & 5.00 \\
Sunflower oil & 2.90 & 4.40 \\
Limestone & 0.90 & 0.60 \\
Di-calcium phosphate & 0.70 & 0.90 \\
Salt & 0.30 & 0.10 \\
Mixtures vitamins and minerals* & 0.20 & 0.20 \\
Total & $100.00 \%$ & $100.00 \%$ \\
\hline Calculated chemical analysis $(\%) * *$ & & 20.00 \\
Crude protein & 23.00 & 3195.3 \\
ME, Kcal/Kg feed & 3027.00 & 1.10 \\
Lysine & 1.20 & 0.46 \\
Methionine & 0.49 & 0.32 \\
Cysteine & 0.36 & 0.76 \\
Calcium & 0.84 & \\
\hline
\end{tabular}

Protein concentrate: Brocon Special W (Netherland source) contain: (crude protein 40\%, fat 2\%, crude fiber 2\%, energy 2107 Kcal, methionine $3.7 \%$, Lysine $3.85 \%$, calcium $5 \%$ and available phosphorus $4.68 \%$.

*: Mixture vitamin and minerals contains:

Vit. A, 12000000 IU; Vit. D3, 2000000 IU; Vit. E, 10 g; Vit. K3, 2.0 g; Vit. B1; 1.0 g; Vit. B2, 5 g; Vit. B6;1.5 g; Vit. B12, $10 \mathrm{mg}$; choline choloride, $250 \mathrm{~g}$; Biotn, $50 \mathrm{mg}$; folic acid,1 g; nicotinic acid, $30 \mathrm{~g}$; Ca Pantothenate, $10 \mathrm{~g}$; Zn, $50 \mathrm{~g} ; \mathrm{Cu}, 10 \mathrm{~g}$; $\mathrm{Fe}, 30 \mathrm{~g}$; Co, $100 \mathrm{mg}$; Se, $100 \mathrm{mg}$; I, $1 \mathrm{~g} ; \mathrm{Mn}, 60 \mathrm{~g}$ and antioxidant, $10 \mathrm{~g}$ and complete to $3.0 \mathrm{~kg}$ by calcium carbonate. **: Chemical analysis calculated according to NCR (1994), ** The chemical composition was calculated according to the analysis of feed materials (NRC, 1994).

Heparinized blood samples for chemical analysis were individually obtained from 5 birds randomly chosen from each group at the end of the experiment (the 5th week of birds' age) from the wing vein. Heparinized blood samples were centrifuged at 2500 rpm for 15-min. Plasma samples were then stored in the deep freezer at approximately $-15^{\circ} \mathrm{C}$ till the time of chemical analysis. Chemical analysis of blood plasma samples were carried out by calorimetrically using commercial chemical kits (Bio-meriex, laboratorus reagent and products, France) for determination of plasma total protein, albumin (A), globulin (G), plasma total cholesterol, high-density lipoproteins (HDL), low-density lipoprotein (LDL), triglycerides, plasma alanine transaminase (ALT) and aspartate transaminase (AST), plasma malondialdehyde (MDA), glutathione (GSH), glucose, plasma uric acid and creatinine. Analysis of variance was calculated on all data obtained using the general Linear Models Procedures (SAS, 2006). Significant differences between treatments means were determined using Duncan's New Multiple-Rang test (Duncan, 1955).

\section{Results and Discussion}




\subsection{Plasma protein fraction}

Data presented in Table (2) showed the effect of the oxidative stress and the addition of white tea leaves powder (WT) to the ration on plasma protein fraction of broiler chickens. Results obtained revealed that significant differences $(\mathrm{P}<0.05)$ between birds drinking normal water (NW) and those drinking normal water with $\mathrm{H}_{2} \mathrm{O}_{2}$ (exposing on oxidative stress) as well as those fed diet supplemented with the different levels of WT. it is clearly observed that chicks which provided with NW showed higher plasma total protein, albumin (A), and $\mathrm{A} / \mathrm{G}$ ratio compared to those provided with $\mathrm{NW}+\mathrm{H}_{2} \mathrm{O}_{2}$. Furthermore, chicks fed diets supplemented with different levels of WT showed the higher plasma protein fractions compared to control group. Chicks fed diets supplemented with WT at levels of $3 \mathrm{~g} / \mathrm{kg}$ diet and drinking NW showed the highest plasma total protein, albumin and $\mathrm{A} / \mathrm{G}$ ratio compared with the other treatments applied and control group, while it was recorded the intermediate value of plasma globulin. These results may attributed to the beneficial activity of white tea compounds such as flavonoids, catechin which act as an effective antioxidant which play an important role in improve a health status of birds (Saffari and Sadrzadeh, 2004). The interaction between NWxWT3 significantly increased plasma total protein, albumin and $\mathrm{A} / \mathrm{G}$ ratio, while the interactions between OWxWT2 and OWxWT3 significantly increased plasma globulin compared with different interaction applied.

Table 2: The effect of type of water and dietary supplementation with white tea levels on plasma protein fractions

\begin{tabular}{|c|c|c|c|c|c|}
\hline & Items & $\begin{array}{c}\text { Total protein } \\
\text { (g/dl) }\end{array}$ & $\begin{array}{c}\text { Albumin } \\
(\mathrm{g} / \mathrm{dl})\end{array}$ & $\begin{array}{c}\begin{array}{c}\text { Globulin } \\
\text { (g/dl) }\end{array} \\
\end{array}$ & $\mathrm{A} / \mathrm{G}$ ratio \\
\hline \multirow{2}{*}{$\begin{array}{l}\text { Drinking } \\
\text { water }\end{array}$} & Normal water (NW) & $4.03 \pm 0.09^{a}$ & $2.35 \pm 0.06^{a}$ & $1.68 \pm 0.06^{a}$ & $1.41 \pm 0.06^{a}$ \\
\hline & $\begin{array}{c}\text { Oxidative water } \\
(0.5 \%)(\mathrm{OW})\end{array}$ & $3.69 \pm 0.09^{b}$ & $1.94 \pm 0.05^{b}$ & $1.75 \pm 0.05^{\mathrm{a}}$ & $1.11 \pm 0.02^{b}$ \\
\hline \multirow{4}{*}{$\begin{array}{l}\text { White Tea } \\
\text { (WT) }\end{array}$} & WT1 (0 g/ diet) & $3.44 \pm 0.08^{d}$ & $1.93 \pm 0.08^{c}$ & $1.51 \pm 0.08^{b}$ & $1.30 \pm 0.11^{\mathrm{a}}$ \\
\hline & WT2 (1 g/kg diet) & $3.77 \pm 0.11^{c}$ & $2.09 \pm 0.10^{b}$ & $1.68 \pm 0.05^{a}$ & $1.25 \pm 0.08^{\mathrm{a}}$ \\
\hline & WT3 (2 g/kg diet) & $4.02 \pm 0.09^{b}$ & $2.18 \pm 0.11^{b}$ & $1.84 \pm 0.03^{a}$ & $1.19 \pm 0.08^{a}$ \\
\hline & WT4 (3 g/kg diet) & $4.20 \pm 0.07^{\mathrm{a}}$ & $2.38 \pm 0.10^{\mathrm{a}}$ & $1.83 \pm 0.04^{\mathrm{a}}$ & $1.31 \pm 0.08^{a}$ \\
\hline \multirow{8}{*}{ Interaction } & NWxWT1 & $3.57 \pm 0.10^{e}$ & $2.08 \pm 0.07^{\text {de }}$ & $1.48 \pm 0.17^{c}$ & $1.45 \pm 0.21^{\mathrm{a}}$ \\
\hline & NWXWT2 & $3.99 \pm 0.06^{\mathrm{cd}}$ & $2.30 \pm 0.06^{b c}$ & $1.69 \pm 0.11^{\mathrm{abc}}$ & $1.37 \pm 0.12^{\mathrm{ab}}$ \\
\hline & NWXWT3 & $4.20 \pm 0.030^{\mathrm{ab}}$ & $2.42 \pm 0.05^{b}$ & $1.79 \pm 0.02^{\mathrm{a}}$ & $1.35 \pm 0.04^{\mathrm{ab}}$ \\
\hline & NWXWT4 & $4.36 \pm 0.01^{\mathrm{a}}$ & $2.60 \pm 0.03^{a}$ & $1.76 \pm 0.04^{\mathrm{ab}}$ & $1.48 \pm 0.05^{\mathrm{a}}$ \\
\hline & OWxWT1 & $3.32 \pm 0.06^{\mathrm{f}}$ & $1.77 \pm 0.04^{\mathrm{g}}$ & $1.54 \pm 0.02^{b c}$ & $1.15 \pm 0.01^{b c}$ \\
\hline & OWXWT2 & $3.54 \pm 0.08^{\mathrm{e}}$ & $1.88 \pm 0.04^{f g}$ & $1.66 \pm 0.04^{\mathrm{ab}}$ & $1.13 \pm 0.01^{b c}$ \\
\hline & OWXWT3 & $3.84 \pm 0.06^{d}$ & $1.95 \pm 0.04^{e f}$ & $1.89 \pm 0.04^{a}$ & $1.03 \pm 0.04^{c}$ \\
\hline & OWxWT4 & $4.05 \pm 0.06^{b c}$ & $2.16 \pm 0.03^{\mathrm{cd}}$ & $1.89 \pm 0.02^{\mathrm{a}}$ & $1.14 \pm 0.00^{b c}$ \\
\hline
\end{tabular}

a, b \& c: There is no significant difference $(P>0.05)$ between any two means, within the same column have the same superscript letter.

3.2. Plasma total cholesterol, High-Density Lipoprotein (HDL), Low Density Lipoproteins (LDL) and Triglycerides:

The results obtained in Table (3) showed the effect of the oxidative stress and dietary white tea levels on plasma total cholesterol, HDL, LDL and triglycerides. The results revealed that significant differences $(\mathrm{P}$ $<0.05)$ were found in plasma total cholesterol, HDL, LDL and triglycerides due to diets supplemented with different levels of WT and the interaction between WT levels and type of drinking water. While, there was a significant effect of the type of water on LDL and triglyceride only. The results obtained showed that chicks provided with NW recorded the lower plasma cholesterol, LDL and triglyceride were (127.95, 39.03 and $62.88 \mathrm{mg} / \mathrm{dl}$, respectively) than those recorded by chicks provided with OW which mounted (128.04, 44.38 and $67.33 \mathrm{mg} / \mathrm{dl}$, respectively. However chicks provided with $\mathrm{NW}$ showed higher HDL $(84.76 \mathrm{mg} / \mathrm{dl})$ than those provided with OW $(83.67 \mathrm{mg} / \mathrm{dl})$. This result seemed to be quite logic, since the oxidative stress could has negative effect one bird's physiological activity. Moreover, the results obtained revealed that the groups of birds fed diets supplemented with the different levels of WT showed lower plasma cholesterol, LDL and triglyceride than control group. However, chicks fed diet supplemented with WT levels recorded the higher plasma HDL than control. The interaction between type of water and WT levels showed highly significant effects on plasma total cholesterol, HDL, LDL and triglycerides. The role of white tea in the reduction of low-density lipoproteins and the increase in high-density lipoproteins is due to its high content of flavonoids (Adnan et al., 2013), especially catechins, which are strong antioxidants. One study estimated that the strength of antioxidant in white tea about 100 times more than in vitamin $\mathrm{E}$, and these antagonists may inhibit lipid peroxidation chain reactions (Hollman et al., 1999), which scavenge the varieties of oxygen radicals and nitric. 
Table 3. Effect of type of water and dietary supplementation with white tea levels on plasma total cholesterol, HDL, LDL and triglycerides of broiler chickens

\begin{tabular}{|c|c|c|c|c|c|}
\hline & Items & $\begin{array}{c}\text { Cholesterol } \\
\text { mg/dl }\end{array}$ & $\begin{array}{l}\text { HDL } \\
\mathrm{mg} / \mathrm{dl}\end{array}$ & $\begin{array}{l}\mathrm{LDL} \\
\mathrm{mg} / \mathrm{dl}\end{array}$ & $\begin{array}{c}\text { Triglyceride } \\
\text { mg/dl }\end{array}$ \\
\hline \multirow[b]{2}{*}{$\begin{array}{c}\text { Drinking } \\
\text { water }\end{array}$} & Normal water (NW) & $127.95 \pm 3.80$ & $84.76 \pm 1.80$ & $39.03 \pm 2.62^{b}$ & $62.88 \pm 1.94^{b}$ \\
\hline & $\begin{array}{c}\text { Oxidative water } \\
(0.5 \%)(\mathrm{OW})\end{array}$ & $128.04 \pm 6.64$ & $83.67 \pm 3.63$ & $44.38 \pm 9.83^{a}$ & $67.33 \pm 2.93^{a}$ \\
\hline \multirow{4}{*}{$\begin{array}{c}\text { White Tea } \\
\text { (WT) }\end{array}$} & WT1 (0 g/ diet) & $150.42 \pm 9.62^{\mathrm{a}}$ & $72.07 \pm 3.70^{c}$ & $70.02 \pm 13.53^{a}$ & $75.18 \pm 3.55^{a}$ \\
\hline & WT2 (1 g/kg diet) & $121.33 \pm 4.74^{b}$ & $82.80 \pm 1.32^{b}$ & $38.53 \pm 5.57^{b}$ & $59.28 \pm 3.20^{b}$ \\
\hline & WT3 (2 g/kg diet) & $121.13 \pm 2.18^{b}$ & $88.78 \pm 2.12^{\mathrm{a}}$ & $32.35 \pm 3.88^{b}$ & $62.02 \pm 1.92^{b}$ \\
\hline & WT4 (3 g/kg diet) & $119.10 \pm 1.79^{b}$ & $93.20 \pm 1.47^{\mathrm{a}}$ & $25.90 \pm 1.49^{c}$ & $63.93 \pm 1.56^{b}$ \\
\hline \multirow{8}{*}{ Interaction } & NWxWT1 & $135.80 \pm 15.40^{b}$ & $79.27 \pm 1.68^{c}$ & $39.87 \pm 1.15^{c}$ & $67.7 \pm 2.25^{b}$ \\
\hline & NWXWT2 & $131.37 \pm 1.28^{b}$ & $81.33 \pm 1.45^{c}$ & $50.03 \pm 0.80^{b}$ & $53.73 \pm 3.49^{d}$ \\
\hline & NWXWT3 & $124.37 \pm 1.95^{\mathrm{bc}}$ & $85.43 \pm 2.36^{\text {bc }}$ & $38.93 \pm 3.42^{c}$ & $65.00 \pm 2.02^{b c}$ \\
\hline & NWxWT4 & $120.27 \pm 1.43^{b}$ & $93.00 \pm 2.31^{\mathrm{a}}$ & $27.27 \pm 2.77^{\mathrm{d}}$ & $65.07 \pm 1.73^{\mathrm{bc}}$ \\
\hline & OWXWT1 & $165.03 \pm 3.49^{a}$ & $64.87 \pm 3.72^{d}$ & $100.17 \pm 2.18^{\mathrm{a}}$ & $82.67 \pm 1.41^{a}$ \\
\hline & OWXWT2 & $111.30 \pm 3.14^{c}$ & $84.27 \pm 2.11^{c}$ & $27.03 \pm 4.72^{d}$ & $64.83 \pm 2.85^{b}$ \\
\hline & OWXWT3 & $117.90 \pm 3.07^{b c}$ & $92.13 \pm 2.41^{\mathrm{ab}}$ & $25.77 \pm 4.48^{d}$ & $59.03 \pm 2.34^{\mathrm{cd}}$ \\
\hline & OWXWT4 & $117.93 \pm 3.56^{\mathrm{bc}}$ & $93.40 \pm 2.34^{\mathrm{a}}$ & $24.53 \pm 1.24^{d}$ & $62.80 \pm 2.80^{b c}$ \\
\hline
\end{tabular}

a, b \& c: There is no significant difference $(P>0.05)$ between any two means, within the same column have the same superscript letter.

3.3. Plasmaalanine transaminase (ALT) and aspartate transaminase (AST)

The effect of the type of water and dietary white tea levels on plasma ALT and AST was showed in (table, 4). The results obtained showed significant variations were found in plasma AST and ALT of broiler chickens due to the effect of the type of water and dietary supplementation of white tea levels and the interaction between them. Chicks provided by NW (control group) showed the lower plasma AST and ALT (23.81 and 41.72 U/L, respectively) than those provided with OW which mounted (26.41 and 47.22
$\mathrm{U} / \mathrm{L}$, respectively). It is clearly observed that, broiler chicks fed diets supplemented with white tea levels recorded significantly lower averaged of plasma AST and ALT than control one. The results obtained showed that the group of birds which provided normal water and fed diet supplemented with white tea at level of $3 \mathrm{~g} / \mathrm{kg}$ diet significantly decreased plasma AST and ALT compared with different treatments applied. The improvement lever enzymes function activity could be attributed to the beneficial of white tea compounds which influence of physiological response.

Table 4. Effect of type of water and dietary supplementation with white tea levels on plasma alanine transaminase (ALT) and aspartate transaminase (AST) of broiler chickens

\begin{tabular}{|c|c|c|c|}
\hline & & $\begin{array}{c}\text { ALT } \\
(\mathbf{U} / \mathbf{L})\end{array}$ & $\begin{array}{c}\text { AST } \\
(\mathbf{U} / L)\end{array}$ \\
\hline \multirow{2}{*}{ Drinking water } & $\begin{array}{l}\text { Normal water } \\
\text { (NW) }\end{array}$ & $23.81 \pm 0.48^{b}$ & $41.72 \pm 1.02^{b}$ \\
\hline & $\begin{array}{c}\text { Oxidative water } \\
(0.5 \%)(\mathrm{OW})\end{array}$ & $26.41 \pm 0.30^{a}$ & $47.22 \pm 0.6^{a}$ \\
\hline \multirow{4}{*}{ White Tea (WT) } & WT1 (0 g/ diet) & $26.80 \pm 0.47^{a}$ & $48.04 \pm 0.66^{a}$ \\
\hline & WT2 (1 g/kg diet) & $25.10 \pm 0.82^{b}$ & $45.15 \pm 1.8^{b}$ \\
\hline & WT3 (2 g/kg diet) & $24.37 \pm 0.74^{b}$ & $43.10 \pm 1.39^{c}$ \\
\hline & WT4 (3 g/kg diet) & $24.18 \pm 0.69^{b}$ & $41.60 \pm 1.39^{d}$ \\
\hline \multirow{8}{*}{ Interaction } & NWxWT1 & $26.31 \pm 0.67^{a b}$ & $47.10 \pm 0.96^{b}$ \\
\hline & NWxWT2 & $23.43 \pm 0.34^{c}$ & $41.18 \pm 0.62^{d}$ \\
\hline & NWxWT3 & $22.81 \pm 0.32^{c}$ & $40.08 \pm 0.62^{d e}$ \\
\hline & NWxWT4 & $22.69 \pm 0.35^{c}$ & $38.53 \pm 0.29^{e}$ \\
\hline & OWXWT1 & $27.28 \pm 0.63^{a}$ & $48.98 \pm 0.63^{a}$ \\
\hline & OWXWT2 & $26.76 \pm 0.66^{\mathrm{ab}}$ & $49.12 \pm 0.28^{a}$ \\
\hline & OWxWT3 & $25.93 \pm 0.46^{\mathrm{ab}}$ & $46.12 \pm 0.31^{b c}$ \\
\hline & OWxWT4 & $25.68 \pm 0.24^{b}$ & $44.68 \pm 0.27^{c}$ \\
\hline
\end{tabular}

a, b \& c: There is no significant difference $(P>0.05)$ between any two means, within the same column have the same superscript letter. 
The ability of white tea's to reduce the plasma cholesterol is may be due to the presence of active compounds in its extract such as Catechin and Epigallocatechin, that have a powerful antioxidant activities, the reducing the absorption of cholesterol and increasing the secretion of bile salts where there is a virtual effect in inhibiting liver cholesterol produce (Friedman, 2007), or inhibit the $\beta$-hydroxy- $\beta$ methyl glutary-CoA reductase enzyme responsible for the construction of cholesterol (Bishop, 1999). Furthermore, the presence of flavonoids in the white tea extracts plays an important role in lowering the level of cholesterol within the intestines by increasing its secretion in the defecation and in turn reduces the level of cholesterol in the liver (Ekayanti et al., 2017).

\subsection{PlasmaMalondialdehyde (MDA), Glutathione} (GSH) and glucose

Data presented in Table (5) showed the effect of the type of water and dietary supplementation of white tea levels on plasma Malondialdehyde (MDA),
Glutathione (GSH) and glucose. The results obtained revealed that significant variations were found in plasma MDA and GSH of broilers due to the effect of dietary supplementation of white tea levels and the interaction between white tea levels and the type of water. However, no significant variation was found due to the effect of the type of water on plasma GSH. Broilers chicks fed diet supplemented with white tea levels showed lower plasma MDA and glucose levels than control group. this result agree with those reported by Bursill et al. (2001) and Kuhn et al. (2004) who found that the green tea contains polysaccharides is substance that plays an important role in reducing the level of glucose in the serum However, the broiler chicks fed diet supplemented with white tea levels showed significantly the higher plasma GSH than control group. these results seems quite logic, since the ability of white tea's to reduce the plasma MDA and increase of GSH is may be attributed to the presence of active compounds in its extract such as catechin and epigallocatechin, which has a powerful antioxidant activities.

Table 5. Effect of type of water and dietary supplementation with white tea levels on Plasma MDA, GSH and glucose of broiler chickens

\begin{tabular}{|c|c|c|c|c|}
\hline & Items & $\begin{array}{c}\text { MDA } \\
\text { (U/l) }\end{array}$ & GSH & $\begin{array}{c}\text { Glucose } \\
(\mathrm{mo} / 100 \mathrm{ml})\end{array}$ \\
\hline & Normal water $(\mathrm{NW})$ & $172.56 \pm 7.69$ & $4.05 \pm 0.19$ & $189.17 \pm 4.29$ \\
\hline Drinking water & $\begin{array}{c}\text { Oxidative water } \\
(0.5 \%)(\mathrm{OW})\end{array}$ & $161.32 \pm 13.01$ & $4.37 \pm 0.35$ & $184.83 \pm 6.96$ \\
\hline & WT1 (0 g/ diet) & $216.88 \pm 14.10^{a}$ & $3.15 \pm 0.24^{b}$ & $214.17 \pm 6.77^{\mathrm{a}}$ \\
\hline White Tea & WT2 (1 g/kg diet) & $145.92 \pm 5.06^{b}$ & $4.17 \pm 0.33^{\mathrm{a}}$ & $180.00 \pm 3.02^{b}$ \\
\hline (WT) & WT3 (2 g/kg diet) & $159.75 \pm 9.56^{b}$ & $4.55 \pm 0.33^{\mathrm{a}}$ & $176.83 \pm 4.14^{b}$ \\
\hline & WT4 (3 g/kg diet) & $145.20 \pm 4.70^{b}$ & $4.97 \pm 0.31^{\mathrm{a}}$ & $177.00 \pm 5.26^{b}$ \\
\hline & NWxWT1 & $203.60 \pm 18.03^{a b}$ & $3.57 \pm 0.07^{\mathrm{cd}}$ & $205.67 \pm 11.61^{\mathrm{a}}$ \\
\hline & NWxWT2 & $154.80 \pm 5.96^{\mathrm{cd}}$ & $3.77 \pm 0.18^{\text {bcd }}$ & $181.33 \pm 4.10^{\mathrm{bc}}$ \\
\hline & NWxWT3 & $179.17 \pm 8.17^{b c}$ & $4.17 \pm 0.49^{\mathrm{abc}}$ & $182.67 \pm 6.12^{\mathrm{bc}}$ \\
\hline Intongtion & NWxWT4 & $152.67 \pm 3.72^{\mathrm{cd}}$ & $4.70 \pm 0.42^{\text {abc }}$ & $187.00 \pm 5.13^{b}$ \\
\hline mieraction & OWxWT1 & $230.17 \pm 22.19^{a}$ & $2.73 \pm 0.34^{d}$ & $222.67 \pm 4.70^{\mathrm{a}}$ \\
\hline & OWXWT2 & $137.03 \pm 3.66^{d}$ & $4.57 \pm 0.61^{\mathrm{abc}}$ & $178.67 \pm 5.21^{\mathrm{bc}}$ \\
\hline & OWxWT3 & $140.33 \pm 3.59^{d}$ & $4.93 \pm 0.38^{a b}$ & $171.00 \pm 3.79^{\mathrm{bc}}$ \\
\hline & OWxWT4 & $137.73 \pm 6.38^{d}$ & $5.23 \pm 0.48^{\mathrm{a}}$ & $167.00 \pm 3.46^{c}$ \\
\hline
\end{tabular}

a, b \& c: There is no significant difference $(\mathrm{P}>0.05)$ between any two means, within the same column have the same superscript letter.

\subsection{Plasmauric acid and Creatinine}

The results obtained in Table (6) showed the effect of the type of water and the addition of white tea levels to the diets of broiler chicken on plasma uric acid and creatinine. Significant variations were found in plasma uric acid and creatinine due to the effect of type of water, the addition dietary supplementation of white tea levels and the interaction between them. Chicks provided with normal water showed the lower plasma uric acid and creatinine $(7.90$ and $0.13 \mathrm{mg} / \mathrm{dl}$, respectively) than those provided with oxidative water (8.01 and $0.16 \mathrm{mg} / \mathrm{dl}$ for plasma uric acid and creatinine, respectively). Generally, broiler chicks fed diets supplemented with different levels of white tea significantly decreased plasma uric acid and creatinine than those recorded by control group. Concerning to the interaction effect between the type of water and the dietary supplementation of whit tea 
levels, chicks fed diet supplemented with white tea at a level of $3 \mathrm{~g} / \mathrm{kg}$ diet and provided with normal water showed significantly the lowest average of plasma uric acid and creatinine compared with the other interactions applied.

Table 6. Effect of type of water and dietary supplementation with white tea levels on plasma uric acid and creatinine of broiler chicken

\begin{tabular}{|c|c|c|c|}
\hline & & $\begin{array}{l}\text { Uric acid } \\
\mathrm{mg} / \mathrm{dl}\end{array}$ & $\begin{array}{c}\text { Creatinine } \\
\text { mg/dl }\end{array}$ \\
\hline \multirow{2}{*}{ Drinking water } & $\begin{array}{c}\text { Normal water } \\
(\mathrm{NW})\end{array}$ & $7.90 \pm 0.03^{b}$ & $0.13 \pm 0.00^{b}$ \\
\hline & $\begin{array}{c}\text { Oxidative water } \\
(0.5 \%)(\mathrm{OW})\end{array}$ & $8.01 \pm 0.03^{a}$ & $0.16 \pm 0.01^{\mathrm{a}}$ \\
\hline \multirow{4}{*}{ White Tea (WT) } & WT1 (0 g/ diet) & $8.09 \pm 0.04^{a}$ & $0.17 \pm 0.01^{\mathrm{a}}$ \\
\hline & WT2 (1 g/kg diet) & $7.97 \pm 0.03^{b}$ & $0.14 \pm 0.01^{b}$ \\
\hline & WT3 (2 g/kg diet) & $7.91 \pm 0.03^{c}$ & $0.13 \pm 0.01^{b}$ \\
\hline & WT4 (3 g/kg diet) & $7.84 \pm 0.02^{d}$ & $0.13 \pm 0.00^{b}$ \\
\hline \multirow{8}{*}{ Interaction } & NWxWT1 & $8.03 \pm 0.04^{b c}$ & $0.15 \pm 0.01^{b c}$ \\
\hline & NWXWT2 & $7.90 \pm 0.01^{d}$ & $0.12 \pm 0.01^{d}$ \\
\hline & NWxWT3 & $7.85 \pm 0.01^{\text {de }}$ & $0.12 \pm 0.01^{\mathrm{d}}$ \\
\hline & NWxWT4 & $7.80 \pm 0.01^{\mathrm{e}}$ & $0.12 \pm 0.00^{d}$ \\
\hline & OWxWT1 & $8.16 \pm 0.03^{a}$ & $0.19 \pm 0.00^{\mathrm{a}}$ \\
\hline & OWXWT2 & $8.03 \pm 0.01^{b c}$ & $0.16 \pm 0.00^{b}$ \\
\hline & OWXWT3 & $7.98 \pm 0.01^{c}$ & $0.15 \pm 0.00^{b c}$ \\
\hline & OWxWT4 & $7.88 \pm 0.01 d$ & $0.13 \pm 0.00^{\text {cd }}$ \\
\hline
\end{tabular}

a, b \& c: There is no significant difference $(P>0.05)$ between any two means, within the same column have the same superscript letter.

\section{Conclusion}

It could be concluded from the results obtained that, broiler chicks provided by the normal water showed the better biochemical blood parameters than those received the oxidative water. Moreover, chicks fed diets supplemented with different levels of white tea enhancement in physiological and biochemical blood parameters than control group. Broiler chicks fed diet supplemented with $3 \mathrm{~g} / \mathrm{kg}$ feed and provided with normal water seemed to be adequate to achieve the favorable results of biochemical and physiological parameters.

\section{References}

Adnan, M.; Ahmad, A. and Ahmed, A. (2013). Chemical composition and sensory evaluation of tea (Camellia sinensis) commercialized in Pakistan. Pak J Bot; 45(3): 901-907.

Antan, R. and Shella, W. (2003). Antioxidant effect of tea evidence from human clinical trails. The American Society for Nutritional Sciences.J.Nutr.133: 3285-3292.

Bishop , M.L. (1999). Tea flavonoids : Their functions, utilization and analysis .Trends in Food Science and Technology, 11(4-5): 152-160.

Bölükbaşi and Erhan, M. (2007). Effect of dietary Thyme (Thymus vulgaris) on laying hens performance and Escherichia coli (E. coli) concentration in feces. Atatürk University, the Faculty of Agriculture, Department of Animal Science, 25240, Erzurum, Turkey
Bursill, C.; Roach, P.D.; Bottema, C.D. and Pal, S. (2001). Green tea upregulates the low-density lipoprotein receptor through the sterol-regulated element binding protein in HepG2 liver cells. J. Agric. Food Chem. 49: 5639- 5645.

Costa, L.M.; Gouveia, S.T. and Nobrega, J.A. (2002). Comparison of heating extraction procedures for $\mathrm{Al}, \mathrm{Ca}, \mathrm{Mg}$ and $\mathrm{Mn}$ in tea samples. Ann Sci; 18: 313-318.

Dalkilic, B.; Ciftcil, M.; Guler, T.; Cerci, I.H.; Ertas, O.N. and Guvenc, M. (2009). Influence of Dietary Cinnamon Oil Supplementation on Fatty Acid Composition of Liver and Abdominal Fat in Broiler Chicken. J. Appl. Him. Res., 35: 173-176.

Duncan, B.D. (1955). Multiple range and multiple Ftest: Biometrics, 11:1-42.

Ekayanti, M.; Ardiana, L.; Najib, S.Z.; Sauriasari, R. and Elya, B. (2017). Pharmacognostic and Phytochemical Standardization of White Tea Leaf (Camellia sinensis L. Kuntze) Ethanolic Extracts. Pharmacognosy Journal, Vol 9, Issue 2, Pages:221-226

Friedman, M. (2007). Overview of antibacterial, antitoxin, antiviral,and antifungal activities of tea flavonoids and teas. Mol Nutr Food Res 51: $116-$ 134.

Gargi, S.; Sudeshna, S.C.; Biswajit. B. and Mohan, K. (2017). Biochemical and Microbiological Characterization of White Tea . Journal of Environmental Science., 11(5): 74-80.

Hollman, P.C.H.; Feskens, E.J.M. and Katan, M.B. (1999). Tea flavonols in cardiovascular disease 
and cancer epidemiology. Proc.Exp. Biol. Med.220(4):198-202.

Kuhn, D.J.; Burns, A.C.; Kazin, A. and Ping-Dou, Q. (2004). Direct inhibition of the ubiquitinproteasome pathway by ester bond-containing green tea polyphenols is associated with increased expression of sterol regulatory element-binding protein 2 and LDL receptor. Biochim. Biophys. Acta 1682, 1-10.

Larsen, K. (1972). Creatinine assay by a reactionkinetic principle Clin. Chem. Acta, 41: 209.

NRC, 1994. Nutrient requirements of poultry. $9^{\text {th }}$ rev. Ed. National Academy Pres., Washington DC., USA.

Saffari, Y. and Sadrzadeh, S.M.H. (2004). Green tea metabolite EGCG protects membranes against oxidative damage in vitro. Life Sci. 74: 1513
SAS (2006). SAS User's Guide for Personal Computer. SAS Institute Inc., Cary, NC., USA. Soltan, M.A.; Shewita, R.S. and El-Katcha, M.I. (2008). Effect of dietary anise seeds supplementation on growth performance, immune response, carcass traits and some blood parameters of broiler chickens. International Journal of Poultry Science 7(11): 1078-1088.

Unachukwu, U.J; Ahmed, S.; Kavalier, A.; Lyles, J.T. and Kennelly, E.J. (2010). White and green teas (Camellia sinensis var. sinensis): variation in phenolic,methylxanthine, and antioxidant profiles. J Food Sci. 1;75(6): C541-8.

Wang, Y. and Ho, C.T. (2009). Polyphenolic chemistry of tea and coffee: A century of progress. Journal of Agricultural and Food Chemistry, 57: 8109-8114. 